\title{
An IGF1/insulin receptor substrate-1 pathway stimulates a mitotic kinase (cdk1) in the uterine epithelium during the proliferative response to estradiol
}

\author{
Michael P Walker, Richard P DiAugustine, Ernest Zeringue, Maureen K Bunger, Martina Schmitt, \\ Trevor K Archer and R Gregg Richards
}

Laboratory of Molecular Carcinogenesis, National Institute of Environmental Health Sciences, National Institutes of Health, Mail Drop D4-01, PO Box 12233, Research Triangle Park, North Carolina 27709, USA

(Correspondence should be addressed to T K Archer; Email: archer1@niehs.nih.gov)

\begin{abstract}
Estrogens are potent mitogens for some target organs, such as the uterus, and cancers that develop in this organ might be linked to the proliferative action of these hormones. However, the mechanism by which estrogens influence the cell cycle machinery is not known. We found that a null mutation for the insulin receptor substrate (IRS)-1, a docking protein that is important for IGF1 signaling, compromised hormoneinduced mitosis in the uterine epithelium; BrdU incorporation was not affected. This selective effect on mitosis was associated with a reduction in uterine cyclin B-associated kinase activity; cyclin A-associated kinase activity was not changed. The null mutation also reduced the extent of hormone-induced phosphorylation of endogenous uterine histone $\mathrm{H} 1$, as determined with phospho-specific antiserum. Uterine epithelial cyclin dependent kinase (cdk) 1 was induced
\end{abstract}

in response to hormone, but the level of the kinase protein, as determined by immunoblotting, was noticeably less in the irs 1 null mutant than that in the wild-type (WT) mouse, especially around the time of peak mitosis $(24 \mathrm{~h})$. Since IRS-1 binds/activates phosphatidylinositol 3-kinase (PI3K), the absence of this docking protein could impair signaling of a known pathway downstream of AKT that stimulates translation of cell cycle components. Indeed, we found that phosphorylation of uterine AKT (Ser473) in irs 1 null mutants was less than that in WTs following treatment. Based on earlier studies, it is also possible that an IGF1/IRS-1/PI3K/AKT pathway regulates posttranslational changes in $\mathrm{cdk} 1$. This model may provide insights as to how a growth factor pathway can mediate hormone action on cell proliferation.

Journal of Endocrinology (2010) 207, 225-235

\section{Introduction}

It is well known from laboratory studies of rodents that estradiol $\left(\mathrm{E}_{2}\right)$ is a potent mitogen for uterine luminal and glandular epithelial cells (Tong \& Pollard 2002). This mitotic action extends to other congeners of $E_{2}$ and may contribute to the increased risk of endometrial carcinoma observed in postmenopausal females provided with estrogen replacement therapy (Gambrell et al. 1983). The proliferative response to $\mathrm{E}_{2}$ occurs naturally during the ovarian cycle and during early pregnancy. Hormone interaction with the uterine estrogen receptor- $\alpha(E R \alpha)$ is apparently essential for this action since ovariectomized ER $\alpha$ knockout ( $\alpha$ ERKO) mice exhibit negligible uterine cell DNA synthesis or proliferation in response to $E_{2}$ (Couse et al. 1995). Injection of $E_{2}$ into the ovariectomized rodent increases both the expression of cell cyclins and the activation of cyclin-dependent kinases (cdk). Transcripts for uterine cyclins D (D1-D3), E, A, and B increase, with each cyclin having a specific temporal pattern following estrogen exposure (Altucci et al. 1997,
Tong \& Pollard 1999). In mammalian cells, cyclin A is reported to function during $\mathrm{S}$ phase, as well as during the $\mathrm{G}_{2} / \mathrm{M}$ transition, whereas cyclin B controls entry into mitosis (Minshull et al. 1990, Nurse 1990). There is limited knowledge of the local pathways that link activation of the estrogen receptor with the uterine epithelial cell cycle machinery. For over two decades, investigators have considered the notion that hormone-induced growth factors can serve as mediators of cell proliferation. In this regard, experimental evidence is compiling that supports a functional role for the insulin-like growth factor 1 (IGF1) in estrogeninduced proliferation of uterine epithelial cells. $\mathrm{E}_{2}$ is known to increase the level of IGF1 transcripts in the uterus of some mammals. For instance, IGF1 mRNA increases by 14 -fold in the uterus of the ovariectomized rat as early as $6 \mathrm{~h}$ after treatment with $\mathrm{E}_{2}$ (Murphy et al. 1987). This elevation of the uterine IGF1 ligand leads to activation of the IGF1 receptor and downstream signaling pathways in the uterus (Richards et al. 1996, 1998, Klotz et al. 2000). Other studies show that the insulin receptor substrate-1 (IRS-1), which functions as 
a primary substrate for the insulin and IGF1 receptors, is critical for the mitogenic response of these factors (Waters et al. 1993, Rose et al. 1994, Bruning et al. 1997). The omission of IRS-1 in embryonic fibroblasts by null mutation results in a marked reduction in IGF1-stimulated cell proliferation and phosphatidylinositol 3-kinase (PI3K) activity (Bruning et al. 1997). In situ hybridization studies suggest that the interaction of IGF1 with the uterine epithelial IGF1 receptor occurs through a paracrine-type mechanism, with IGF1 originating in proximal stromal cells (Baker et al. 1996, Cooke et al. 1997). A complex containing the IGF1R, IRS-1, and PI3K occurs in uterine extracts of mice treated with $\mathrm{E}_{2}$ or IGF1 (Richards et al. 1998). Formation of this hormone-induced complex is severely compromised in $\alpha$ ERKO mice (Klotz et al. 2000) and also in IGF1 ${ }^{\mathrm{m} / \mathrm{m}}$ mice (Richards et al. 1998), which have a deficiency in IGF1 (Lembo et al. 1996).

It is well known that IGF1 can stimulate proliferation of a variety of cells in vitro (Lowe 1991). This growth factor was originally referred to as a ' $G_{1}$ progression factor' as an outcome of these earlier studies (Leof et al. 1982, Campisi \& Pardee 1984). However, a more recent investigation of cell cycle kinetics in fibroblasts derived from igf1 $1^{-1}$ null mice reveals a large increase in the duration of the $G_{2} / M$ phase when compared with that of wild-type (WT) cells (Sell et al. 1994). Moreover, when intact igf ${ }^{->-}$null female mice are treated with $E_{2}$, the proportion of uterine epithelial cells in the $G_{1}$ and $S$ phases by $20 \mathrm{~h}$ is not different between WT and mutant mice; however, cell number and mitotic figures are markedly reduced in the $i g f 1^{-/-}$null mice (Adesanya et al. 1999). This is the direct evidence that IGF1 provides a mitogenic stimulus in the uterus in response to $\mathrm{E}_{2}$ and does so by influencing transit time through $G_{2} / M$, rather than $G_{1}$.

The major goal of this study is to identify components of the cell cycle in the uterus that are regulated by the hormoneinduced IGF1 signaling pathway. To achieve this, we use the uterine epithelium of hormone-treated ovariectomized mice as an experimental model (Fagg et al. 1979). This model permits analysis of signaling and cell cycle proteins in the uterine epithelium, while providing the permissive microenvironment for $\mathrm{E}_{2}$ to stimulate cell proliferation (Cooke et al. 2002). Since adult igf $1^{-/-}$null mutant mice are extremely small and can exhibit a high frequency of neonatal lethality (Liu et al. 1993), irs $1^{-/-}$null mutants (Araki et al. 1994) were selected for most of the experiments. As described above, the uterus of the irs $1^{-/-}$mouse should have a compromised IGF1 signaling pathway. Our initial experiments used igf $1^{-/-}$mice to establish that this ligand is critical for $\mathrm{E}_{2}$-stimulated association of PI3K (p85) with IRS-1. Following this, we sought to determine whether irs $1^{-1-}$ null mutants exhibit compromised mitosis in the uterine epithelium in response to $\mathrm{E}_{2}$, as was previously observed with igf $1^{-/-}$null mutants (Adesanya et al. 1999). Finally, we attempted to identify what component(s) of the cell cycle might be regulated by the IGF1/IRS-1 pathway. Our findings indicate that the IGF1/IRS-1 pathway contributes to the mitogenic action of $\mathrm{E}_{2}$ by stimulation of cyclin B-associated cdk1 kinase. This finding may have broad implications with regard to the mechanism by which IGF1 provides a stimulus for cell proliferation in various tissues or neoplasias.

\section{Materials and Methods}

Mice, treatments, and tissue collection

IRS-1 WT (irs $1^{+/+}$) and IRS-1 null mutant (irs $1^{-/-}$) mice on a $\mathrm{C} 57 \mathrm{Bl} / 6 \times 129 \mathrm{~Sv}$ background were generated in our laboratory from heterozygous IRS-1 breeding pairs obtained from Taconic (Germantown, NY, USA) with the permission of Dr Ronald Kahn (Joslin Diabetes Center, Boston, MA, USA). Null mutants were also generated by breeding irs $1^{-1-}$ males with $i r s 1^{+/-}$females. The weight of female irs $1^{-/-}$ mice was $\sim 70 \%$ that of the corresponding WTs. IGF1 WT (igf $1^{+\prime^{+}}$) and IGF1 null mutant (igf $1^{-{ }^{-}}$) mice were generated from heterozygous IGF1 breeding pairs (MF1 $\times 129 /$ Sv hybrids) provided by Dr Argiris Efstratiadis (Columbia University, New York, NY, USA). Tail genomic DNA was screened by PCR to determine the genotype. All of the WT, irs $1^{-/-}$, and igf $1^{-/-}$mice were ovariectomized at 8-13 weeks of age. Procedures for surgery, treatments, and euthanasia were conducted in compliance with the guidelines of the NIEHS, National Institutes of Health Animal Care and Use Committee.

To assess 5-bromo-2-deoxyuridine (BrdU) incorporation, ovariectomized WT and irs $1^{-/-}$mice $(n=8$ per group) were treated with $\mathrm{E}_{2}(0.08 \mu \mathrm{g} / \mathrm{g})$ or vehicle $(4 \% \mathrm{v} / \mathrm{v}$ ethanol PBS) s.c. and killed after $18 \mathrm{~h}$; BrdU (Sigma, $0 \cdot 1 \mathrm{mg} / \mathrm{g}$ i.p.) was injected $2 \mathrm{~h}$ before euthanasia. For mitosis experiments, mice ( $n=4$ per group) were killed $22 \mathrm{~h}$ after hormone treatment; the anti-mitotic compound demecolcine (Colcemid, Sigma, $5 \mu \mathrm{g} / \mathrm{g}$ i.p.) was injected $2 \mathrm{~h}$ before euthanasia. Uteri were excised, and a $5 \mathrm{~mm}$ long transverse section in the middle of each horn was taken and immersed in 10\% neutral-buffered formalin. Paraffin sections were prepared by standard procedures. BrdU was detected in sections with a rat antiBrdU monoclonal antibody that was part of a Vector kit (no. PK4004). All mice were treated with hormone no earlier than 14 days after ovariectomy.

Apoptotic cells were identified in uterine sections with a TACS 2 TdT (TBL) In Situ Apoptosis Detection kit (Trevigen, Gaithersburg, MD, USA) according to the manufacturer's instructions; negative and positive control slides were included in the kit.

\section{Epithelial cell extracts}

Mice were treated with hormone as described above and euthanized at various time points after treatment. The specific intervals (up to $48 \mathrm{~h}$ ) following treatment for the different experiments are shown in the figures. For the 0 time point, mice were treated with $4 \%$ ethanol PBS and immediately killed. Uterine epithelial cells were removed as described 
previously (Fagg et al. 1979, Tong \& Pollard 1999). Briefly, uteri were slit lengthwise and placed in $15 \mathrm{ml}$ tissue culture tubes with chilled extraction buffer (1\% Triton X-100, $150 \mathrm{mM} \mathrm{NaCl}, 1 \mathrm{mM} \mathrm{Na} \mathrm{VO}_{4}, 1 \mathrm{mM} \mathrm{NaF}, 50 \mathrm{mM}$ $\mathrm{Na}_{2} \mathrm{MO}_{4}, 20 \mu \mathrm{g} / \mathrm{ml}$ aprotinin, $20 \mu \mathrm{g} / \mathrm{ml}$ leupeptin, and $4 \mu \mathrm{g} / \mathrm{ml}$ 4-amido-phenylmethylsulfonyl fluoride in $50 \mathrm{mM}$ Tris- $\mathrm{HCl}, \mathrm{pH} 7 \cdot 4)$. A volume of 580 and $400 \mu \mathrm{l}$ buffer was used for each WT and irs $1^{-1-}$ uterus respectively. The uteri were agitated in the presence of seven glass beads $(3.0 \mathrm{~mm}$ diameter) on a Vortex-Genie mixer (30 s on/30 s off) for a total of $5 \mathrm{~min}$. The resulting cell suspension was drawn off and then disrupted ultrasonically ( $3 \times 5 \mathrm{~s}$ bursts) followed by brief centrifugation. The supernatant was transferred to a microfuge tube and stored at $-80^{\circ} \mathrm{C}$. Protein concentration was determined with a Pierce BCA assay kit (Pierce Chemical, Rockford, IL, USA) with bovine albumin $(2 \mathrm{mg} / \mathrm{ml})$ as a standard.

\section{Western immunoblotting and immunoprecipitation}

To remove endogenous IgGs prior to immunoprecipitation, aliquots of supernatants were cleared by incubating with $100 \mu \mathrm{l}$ washed protein A-Sepharose (CL-4B, Amersham Pharmacia Biotech) for $30 \mathrm{~min}$ at $4{ }^{\circ} \mathrm{C}$. For immunoprecipitation, the cleared aliquots $(300-450 \mu \mathrm{g}$ protein) were incubated with $5 \mu \mathrm{g}$ antibody for $2 \mathrm{~h}$ at $4{ }^{\circ} \mathrm{C}$. After incubation with the antibody, the supernatants were incubated with the protein A-Sepharose for an additional $2 \mathrm{~h}$ at $4{ }^{\circ} \mathrm{C}$. Antibody/protein A-Sepharose pellets were washed three times with the extraction buffer and subjected to kinase assays or boiled for $5 \mathrm{~min}$ in Laemmli sample buffer. After boiling, the precipitates were stored at $-20^{\circ} \mathrm{C}$. Aliquots of mouse uterine epithelial cell extracts or immunoprecipitates were boiled for an additional $2 \mathrm{~min}$, subjected to SDS-PAGE, and then transferred to polyvinylidene fluoride (Immobilon-P) membrane (Millipore, Bedford, MA, USA). The membrane was blocked with either 5\% bovine albumin/Tris-buffered saline (TBS) with $0 \cdot 1 \%$ Tween 20 or $5 \%$ nonfat dry milk/PBS and incubated with a dilution of specific antibody. For cdk1, where cytokeratin 18 was used as a loading control, the membrane was cut just above the $37 \mathrm{kDa}$ protein marker. The lower portion (cdk1) was blocked with 1\% BSA/TBS-Tween, and the upper portion (cytokeratin 18) was blocked with 5\% nonfat dry milk/PBS.

Antibodies (catalog number) to IRS-1 (06-248), p85 (06-195), cdk1 (06-141), and cdk2 (05-596) were purchased from Upstate (Temecula, CA, USA); antibodies to cyclin A (sc-596), cyclin B1 (sc-595), and cytokeratin 18 (sc-28264) were from Santa Cruz Biotechnology (Santa Cruz, CA, USA); antibodies to AKT (9272) and phosphoAKT (Ser473) (9271) were from Cell Signaling Technology (Beverly, MA, USA).

Each membrane was then incubated with a HRP-conjugated donkey anti-rabbit (NA9340) (Amersham Biosciences) or goat anti-mouse $\operatorname{IgG}$ secondary antibody (A3682) from Sigma.
Immunoreactive proteins were detected using enhanced chemiluminescence (Amersham Pharmacia Biotech).

Six trials were used to obtain immunoblots of uterine cdk1 and cdk2 for up to $30 \mathrm{~h}$ after $\mathrm{E}_{2}$ treatment of WT versus irs $1^{-1-}$ mice. Four trials were used to examine uterine cdk1 levels in both the groups $24 \mathrm{~h}$ after $\mathrm{E}_{2}$ treatment with cytokeratin 18 as a loading control. Four trials were also used to analyze $\mathrm{p}$-AKT/AKT in both the groups in a time-course study. In these experiments, different extracts were analyzed for each trial. Densitometric scans of immunoblot bands were made with an Alpha Innotech FluorChem FC2 Imaging System.

\section{Microarray analysis}

Fold changes in mouse uterine $c \mathrm{dk} 1$ and $c \mathrm{dk} 2$ transcripts following treatment with $E_{2}$ were retrieved from the microarray data offered by Sylvia C Hewitt and Dr Bonnie Deroo (NIEHS, NIH). Details of the experimental design have been published (Hewitt et al. 2003), and the repository for the microarray data is accessible at NCBI's Gene Expression Omnibus (GEO, http://www.ncbi.nlm.nih.gov/ geol/); accession numbers GSE4664 and GSE4615.

\section{Quantitative real-time PCR}

Uteri were obtained from control ( $0 \mathrm{~h} ; n=4$ for each group) and estrogen-treated mice ( $24 \mathrm{~h} ; n=6$ for each group). Each uterus removed was immediately placed on ice in a tube containing $1.5 \mathrm{ml}$ RNAlater Stabilization Reagent (Ambion, Austin, TX, USA). RNA was extracted with the RNeasy Mini kit (Qiagen) according to the manufacturer's instructions. Uteri were transferred to the RLT buffer $(0 \cdot 6 \mathrm{ml}$ per uterus) containing $\beta$-mercaptoethanol $(15 \mu \mathrm{l} / \mathrm{ml})$, and homogenized with an Omni Model TH-115 hand-held homogenizer $(7 \mathrm{~mm}$ sawtooth probe with three bursts at full power, each at ten seconds). RNA isolation was followed by a DNA removal step with DNase I. One microgram total RNA was then reverse transcribed using a Gene Amp PCR 29 System 9700 (Applied Biosystems, Foster City, CA, USA) and the SuperScript First-Strand Synthesis System 30 (Invitrogen).

Quantitative real-time PCR was performed with the Power SYBR Green PCR Master Mix (Applied Biosystems) on a Bio-Rad iCycler (Bio-Rad). The primers for mouse cdk1 were 5'-GGA-CCT-CAA-GAA-GTA-CCT-GGA-C$3^{\prime}$ (forward) and 5'-CCC-TGG-AGG-ATT-TGG-TGTAAG- $3^{\prime}$ (reverse). The primers for mouse actin were $5^{\prime}$-TGA-CAG-GAT-GCA-GAA-GGA-GA-3' (forward) and $5^{\prime}$-CGC-TCA-GGA-GGA-GCA-ATG-3' (reverse). The cDNAs were amplified for 40 cycles $\left(95^{\circ} \mathrm{C} / 10 \mathrm{~min} \rightarrow\right.$ $\left.\left(95^{\circ} \mathrm{C} / 15 \mathrm{~s} \rightarrow 60^{\circ} \mathrm{C} / 30 \mathrm{~s}\right)\right)$. Controls included the omission of template or primers. Melt curves of both the amplicons indicated the presence of a single product and the absence of primer-dimer formation. Relative quantitation of $c \mathrm{dk} 1$ expression was determined by the comparative $C_{\mathrm{t}}$ method (Pfaffl 2001) with actin as the endogenous reference gene. 
Real-time PCR efficiencies for the cdk1 $(E=1.97)$ and actin $(E=1.98)$ were determined from the Q5 Optical System Software (Bio-Rad).

\section{Cyclin-associated kinase assay}

Uterine epithelial extracts were prepared as described above and stored at $-80^{\circ} \mathrm{C}$. Equal amounts of WT and $\mathrm{KO}$ extracts ( $\sim 400 \mu \mathrm{g}$ protein) were diluted to $0.5 \mathrm{ml}$ with the extraction buffer. After preclearing the sample with protein A-Sepharose, $5 \mu \mathrm{g}$ anti-cyclin B (Upstate) or anti-cyclin A (Santa Cruz) were reacted with the sample for $2 \cdot 5 \mathrm{~h}$. Protein A-Sepharose was added, and the immunoprecipitates collected were washed three times with the extraction buffer and then three times with the $\mathrm{cdk} 1 / \mathrm{cdk} 2$ kinase assay buffer

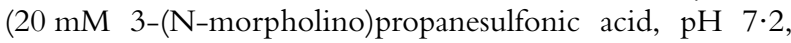
$25 \mathrm{mM}$ glycerol phosphate, $5 \mathrm{mM}$ EGTA, $1 \mathrm{mM}$ sodium orthovanadate, and $1 \mathrm{mM}$ dithiothreitol). The kinase reaction was carried out according to the instructions of the $\mathrm{cdk} 1 / \mathrm{cdk} 2$ kinase assay kit (Upstate). Kinase activity of the immunoprecipitate was carried out in the assay buffer containing $10 \mu \mathrm{Ci}\left[\gamma_{-}{ }^{32} \mathrm{P}\right] \mathrm{ATP} \quad(3000 \mathrm{Ci} / \mathrm{mmol}), 90 \mu \mathrm{M}$ ATP, and $14 \mathrm{mM} \mathrm{MgCl}_{2}$. Histone $\mathrm{H} 1(0 \cdot 4 \mu \mathrm{g} / \mu \mathrm{l})$ was the exogenous substrate. The mixture was incubated for $10 \mathrm{~min}$ at $30^{\circ} \mathrm{C}$. The assay was stopped by placing the reaction tubes on ice and adding gel sample loading buffer. Sample proteins were separated on 4-20\% Tris Ready Gels (Bio-Rad) and transblotted to Immobilon-P membrane. Five separate trials, each with different uterine extracts, were used for the kinase assays. Detection was made by autoradiography and phosphoimaging (Storm 860 Molecular Imager).

\section{In situ histone (H1) phosphorylation}

Nuclei were isolated from whole uteri following homogenization in a detergent-containing buffer, as described previously (Archer et al. 1991). Nuclei were resuspended in $0 \cdot 2 \mathrm{M} \mathrm{H}_{2} \mathrm{SO}_{4}$ and proteins in the soluble fraction precipitated with 5 volumes of ethanol. Ten micrograms isolated histones were separated by SDS-PAGE and transferred onto polyvinylidene fluoride membrane. Immunoblotting procedures were similar to those described above. The membrane was probed with antibodies $(1-2 \mu \mathrm{g} / \mathrm{ml})$ developed in rabbits against mouse $\mathrm{H} 1.3$ amino acids $15-27$ containing a phosphate at Thr18 (Deterding et al. 2008). A test of the antibody against chromatographically purified $\mathrm{H} 1$ isoforms revealed recognition of only $\mathrm{H} 1.3$ and $\mathrm{H} 1.4$ isoforms in mouse cells; the antibody did not detect an $\mathrm{H} 1.3$ peptide phosphorylated at Ser173. Three separate trials, each with different uterine extracts from WT and irs $1^{-/-}$uteri, were used for the in situ histone phosphorylation experiments.

\section{Statistical analysis}

Statistical significance was determined by the Student's $t$-test; two-sided $P \leq 0 \cdot 05$ was considered statistically significant.

\section{Results}

\section{IGF1 is required for $E_{2}$-induced IRS-1 activation}

Since we intended to use the $i r 1^{-/-}$mice to compromise the IGF1R signaling pathway, it was important to ascertain at the outset that the IRS-1 docking protein requires IGF1 for activation of $\mathrm{PI} 3 \mathrm{~K}$ in response to $\mathrm{E}_{2}$. To demonstrate this, ovariectomized female WT and igf $1^{-/}$mice were treated with $\mathrm{E}_{2}(6 \mathrm{~h})$, and the immunoprecipitates of IRS-1 from uterine epithelial extracts were evaluated for the PI3K regulatory subunit (p85). As shown in Fig. 1, the immunoprecipitates of uterine IRS-1 from WT mice (lanes $1-4)$ revealed the expected increased association of $\mathrm{p} 85$ as a result of hormone treatment. In contrast, uterine IRS-1 from hormone-treated $i g f 1^{-/-}$mice (lanes 5-9) was not associated with p85. These findings indicate that the IGF1 ligand is a required intermediate for estrogens to activate IRS-1 and stimulate binding of p85 to IRS-1 in the uterus. In addition, these data rule out the participation of another IGF1R ligand, e.g. IGF2, that might function in the absence of IGF1 to stimulate the activation of IGF1R and IRS-1 (Osborne et al. 1989).

$E_{2}$-stimulated uterine epithelial proliferation is compromised in irs1 ${ }^{-1-}$ mice

Since IGF1 was critical for $\mathrm{E}_{2}$-induced activation of uterine IRS-1, mice with an IRS-1 null mutation could provide insights as to the importance of an IGF1/IGF1R/IRS-1 pathway in the proliferative response of uterine epithelial cells to $\mathrm{E}_{2}$. In order to determine this, ovariectomized adult irs $1^{-/-}$and WT (irs $1^{+/+}$) female mice were treated with $\mathrm{E}_{2}$, and the uterine epithelium was examined for the proportion of cells in the $\mathrm{S}$ phase and in the mitosis. The proliferative response of the uterine epithelial cells to $E_{2}$ in the adult mouse is considered to begin with a drastic shortening of the $G_{1}-S$

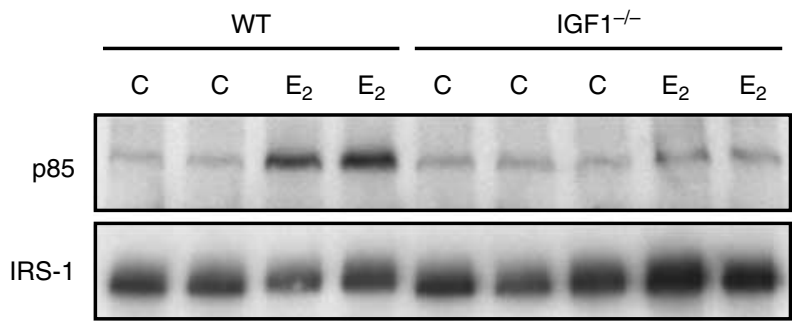

Figure 1 Binding of the PI3K regulatory subunit (p85) to uterine IRS-1 in wild-type (WT) and igf $1^{-/-}$mice treated with estradiol. Ovariectomized mice were treated with estradiol $\left(\mathrm{E}_{2}\right)$ or vehicle (C, control), and uterine epithelial extracts were obtained $6 \mathrm{~h}$ later. Aliquots of the extracts were incubated with anti-IRS-1 antiserum. Immunoprecipitates were separated by SDS-7.5\% PAGE and then immunoblotted with anti-p85 antiserum (upper panel) or anti-IRS-1 antiserum (lower panel). Other details of the treatment, extraction, and immunoblotting procedures are described in Materials and Methods. Each lane represents analyses of a different animal. 

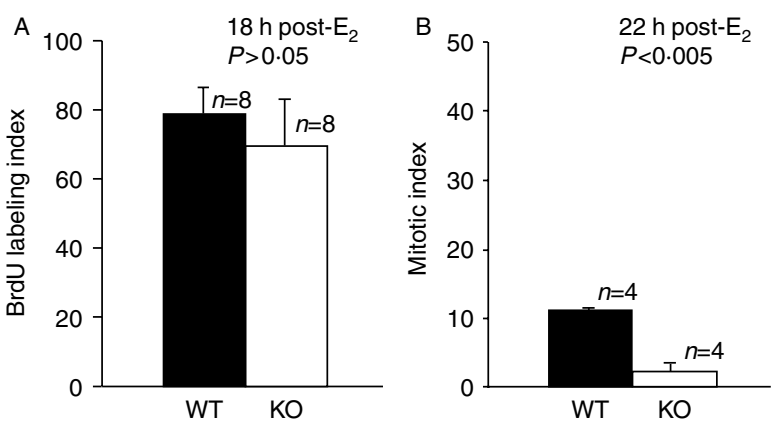

Figure $2 \mathrm{BrdU}$ uptake and mitosis in uterine epithelial cells of estradiol-treated wild-type and irs $1^{-1-}$ mice. (A) Mice were treated with estradiol and killed $18 \mathrm{~h}$ later. BrdU was injected $2 \mathrm{~h}$ prior to euthanasia. Standard methods were used to prepare uterine sections for examination by light microscopy. BrdU was detected in epithelial cells with a rat anti-BrdU monoclonal antibody. The estrogen-stimulated incorporation of $\mathrm{BrdU}$ into uterine epithelial cells of $i r s 1^{-1-}(\mathrm{KO})$ mice was not significantly different $(P>0 \cdot 05)$ from that of wild-type (WT) mice. (B) Mitosis in uterine epithelial cells was determined by injecting demecolcine into mice $20 \mathrm{~h}$ after hormone treatment, followed by euthanasia at $22 \mathrm{~h}$. Further details of the procedures used are described in Materials and Methods. In $(A$ and $B)$, each bar represents the mean \pm s.D.; $n$ is the number of mice used in each group. For both BrdU uptake (A) and mitosis (B), $\sim 500$ epithelial cells were counted in each uterine section. The mitotic index of the $\mathrm{KO}$ mice was significantly different from that of WT mice at $P<0 \cdot 005$.

transition rate. The epithelial cells exhibit a near-synchronous wave of DNA synthesis beginning about $10 \mathrm{~h}$ after hormone treatment; this is followed by mitosis that peaks around 20-24 h. To identify cells in the $\mathrm{S}$ phase, BrdU was injected into animals that were previously treated with $\mathrm{E}_{2} 16 \mathrm{~h}$ earlier. Negligible incorporation of BrdU into uterine epithelial cells occurred when WT or mutant mice were injected with vehicle. Incorporation of $\mathrm{BrdU}$ was apparent in both the groups of mice, and the proportion of cells that incorporated BrdU (labeling index) in irs $1^{-/-}$mice $(70 \pm 13$, mean \pm s.D. $)$ was not significantly different $(P>0 \cdot 05)$ from that of WTs (79 \pm 8 , mean \pm s.D.; Fig. 2A). The fraction of epithelial cells undergoing mitosis was determined at $22 \mathrm{~h}$ after hormone treatment. At this time, epithelial cells of the irs $1^{-/-}$mice had approximately one-sixth the frequency of mitotic figures $(1 \cdot 8 \pm 1 \cdot 2$, mean \pm s.D. $)$ as that of WTs $(10 \cdot 5 \pm 0 \cdot 3$, mean \pm s.D.; $P<0.005$; Fig. $2 \mathrm{~B}$ ). These data suggest that the IRS-1 null mutation affects the rate of transit of uterine epithelial cells through $\mathrm{G}_{2} / \mathrm{M}$ without impairing recruitment of cells into $G_{1} / S$ in response to $E_{2}$. The effects obtained with the irs $1^{-1-}$ mice with regard to hormone stimulation of the uterine epithelial cell cycle are similar to that reported previously for igf $1^{-/-}$mice (Adesanya et al. 1999). In both cases, the null mutation affected the number of cells in mitosis but not the cells in the $\mathrm{S}$ phase. This functional overlap indicates that IGF1 and IRS-1 are part of the same signaling pathway that mediates hormonal stimulation of mitosis of cells in the uterine epithelium. The decrease in the number of mitotic figures observed at $22 \mathrm{~h}$ after $\mathrm{E}_{2}$ treatment in irs $1^{-/-}$mice could not be explained by a difference in apoptosis. Evaluation of uterine sections at this time point for detection of fragmented DNA in situ end labeling showed no detectable apoptosis in the epithelium of WT or irs $1^{-/-}$ mutant mice (data not shown).

The IRS-1 null mutation reduces the $E_{2}$-induced increase in cdk1 (p34) protein but not in $m R N A$

The significant decrease in hormone-induced mitosis in the uterine epithelium of irs $1^{-/-}$mice prompted us to consider an effect of the mutation on the major mitotic kinase cdk1. In the mammal, cdk1 kinase is poorly expressed in normal quiescent cells but accumulates during the $\mathrm{S}$ phase and peaks during the $G_{2}$ and $M$ phases of the cell cycle (Kim et al. 1992, Loyer et al. 1994). As shown in Fig. 3A, microarray analysis of WT mouse uterine RNA reveals that the level of cdk1 transcripts increases markedly by $24 \mathrm{~h}$ after treatment with $\mathrm{E}_{2}$, whereas the level of cdk2 transcripts was essentially invariate during this period. The influence of $\mathrm{E}_{2}$ on uterine $c d k 1$
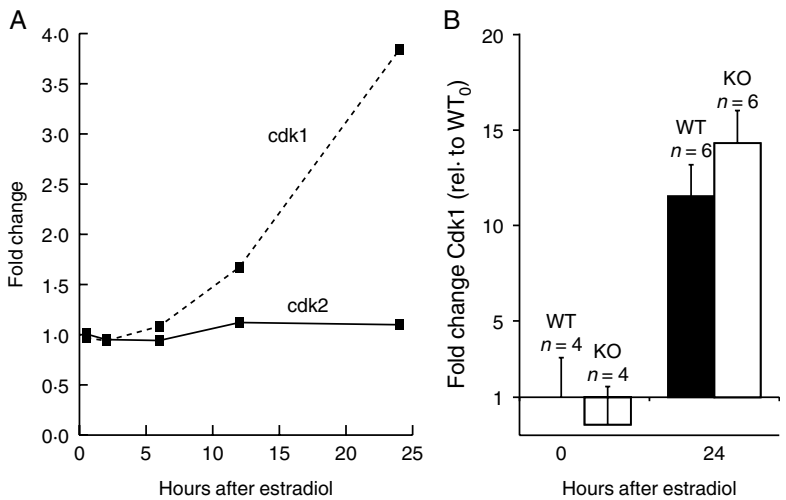

Figure 3 Changes in uterine cdk1 transcripts in wild-type and irs $1^{-1-}$ mice after treatment with estradiol. (A) Total RNA was isolated from whole uteri of $\mathrm{C} 57 \mathrm{BL} / 6$ (ovariectomized) mice at the indicated time points after treatment with estradiol. The plots compare the estradiol-induced fold changes in uterine gene expression of cdk1 against that of cdk2, as determined by microarray analyses. Details of the microarray are described in Materials and Methods. The plots were constructed from values given at the website in Hewitt et al. (2003). (B) Total RNA was isolated from whole uteri of ovariectomized wild-type and irs $1^{-1-}$ mice before and after treatment with estradiol. cDNA was prepared from $1 \mu \mathrm{g}$ RNA and used for quantitative real-time PCR.

Quantitation was made by the comparative $C_{\mathrm{t}}$ method with actin as the endogenous reference gene. After calculating the $C_{\mathrm{t}}$ (cdk1 minus actin), the values $\left(C_{t}\right)$ were determined relative to that for untreated wild types. Each bar represents the mean \pm s.D.; $n$ is the number of mice used in each group. Note that the mean value for the untreated IRS-1 $(\mathrm{KO})$ was $<1 \cdot 0$. Cdk1 transcript level was increased in wild-type (WT) and KO animals $24 \mathrm{~h}$ after hormone treatment; the value for $\mathrm{KO}(24 \mathrm{~h})$ was significantly greater than that of WT ( $24 \mathrm{~h}$ ) at $P<0 \cdot 05$. Further details of the procedures and primer sequences are described in Materials and Methods. 
mRNA in WT mice was compared with that of irs $1^{-/-}$by quantitative PCR analyses using the comparative $\left(C_{\mathrm{t}}\right)$ method with actin as the reference gene. As shown in Fig. 3B, cdk1 transcripts increased in both the groups by $24 \mathrm{~h}$ after estrogen treatment. Interestingly, the level of uterine $c d k 1 \mathrm{mRNA}$ in the IRS-1 null mutants was significantly greater $(P<0 \cdot 05)$ than that of the WT mice at this time point.

To compare the levels of cdk1 protein, the extracts of WT and mutant uterine epithelium were prepared at various time points after hormone treatment and evaluated by immunoblotting. In accordance with the microarray and quantitative PCR data, cdk1 (p34) protein in the quiescent uterine epithelium of ovariectomized mice (time 0 ), WT or irs $1^{-/-}$, was below the level of detection (Fig. 4A). When mice were treated with $\mathrm{E}_{2}$, uterine cdk1 increased and could be readily detected by $18 \mathrm{~h}$ in WT mice. In contrast, the uterine cdk1 abundance in irs $1^{-/-}(\mathrm{KO})$ mice was generally much less than that observed in WTs at the corresponding

A

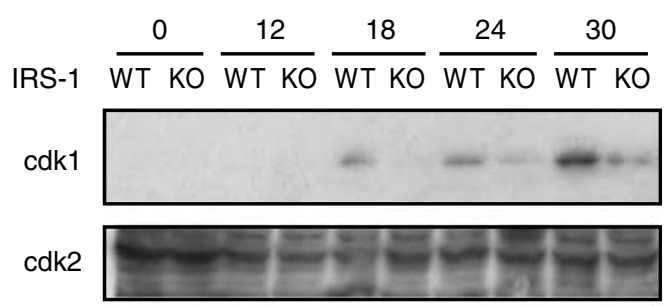

B

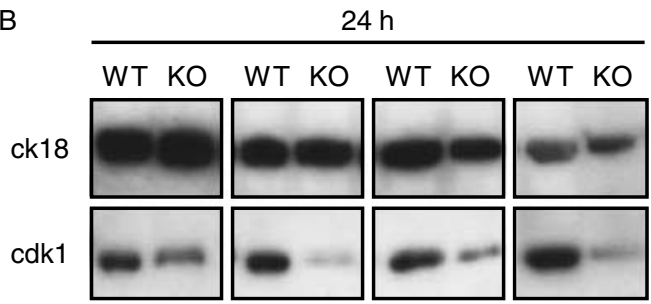

Figure 4 Time-course analyses of cdk1 and cdk2 (immunoreactivity) in uterine epithelial extracts of wild-type and irs $1^{-1-}$ mice. Ovariectomized wild-type (WT) and $\operatorname{irs}^{-1-}$ (KO) mutant mice were treated with estradiol, and uterine epithelial extracts were obtained at the time points indicated. Mice at the 0 time point did not receive hormone. Proteins $(\sim 30 \mu \mathrm{g})$ in aliquots from the extracts were separated by SDS-PAGE and immunoblotted for cdk1 or cdk2. Further details of the extraction and immunoblotting are described in Materials and Methods. In (A), immunoblots of uterine cdk1 and cdk2 are compared for up to $30 \mathrm{~h}$ after estradiol treatment. The results are representative of six different trials. Extracts for each trial (time course) were prepared on separate days; each lane represents an extract from one mouse uterus. In (B), immunoblots of cdk1 from wild-type (WT) and $i r s 1^{-1-}(\mathrm{KO})$ mouse uterine extracts are compared. All the extracts were obtained from uteri $24 \mathrm{~h}$ after hormone treatment. Extracts from each of the four pairs of blots (WT versus KO) were prepared on different days; each lane represents an extract from one mouse uterus. Cytokeratin 18 (ck18), an epithelial marker, was a loading control. As determined by densitometry, KO cdk1 levels $(0 \cdot 41 \pm 0 \cdot 09$, mean \pm s.D. $)$ were significantly less $(P<0 \cdot 005)$ than that of $\mathrm{WT}(1 \cdot 16 \pm 0 \cdot 14$, mean \pm s.D. $) ; \mathrm{KO} / \mathrm{WT}=0 \cdot 35$. intervals after hormone treatment (Fig. 4A). In the four trials that analyzed the extracts from uteri obtained $24 \mathrm{~h}$ after estrogen treatment, the levels of $\mathrm{cdk} 1$ protein in mutants were significantly less $(P<0.005)$ than that of WTs: $\mathrm{KO}(0 \cdot 41 \pm 0 \cdot 09$, mean \pm s.D. $)$ versus WT $(1 \cdot 16 \pm 0 \cdot 14$, mean \pm s.D.); KO/WT $=0.35$ (Fig. 4B).

For both WTs and mutants, the level of hormone-induced cdk1 was highest at the 30 -h time point, which is after peak mitosis in this model. It is not known whether treatment with $E_{2}$ alone ('unopposed') favors this pattern, which might differ considerably from that of the intact female exposed to sequential cycles of estrogens and progestins. Levels of cdk2 (p33) kinase, which forms a heterodimer with cyclin A or cyclin E, were also examined in the uterine extracts of WT and irs $1^{-1-}$ mice treated with hormone. As shown in Fig. 4 (upper panel), cdk2, in contrast to $\mathrm{cdk} 1$, was detected in the extracts before and after hormone treatment. Hormone treatment did not elevate uterine $\mathrm{cdk} 2$ protein levels, which is in accordance with the microarray findings (Fig. 3A). The discrepancy observed for cdk1 in WT and irs $1^{-1-}$ mice was not apparent for $\mathrm{cdk} 2$.

The stimulation of $A K T$ phosphorylation and cyclin B-associated kinase by $E_{2}$ is reduced in the irs1 ${ }^{-1}$ mutant

Since hormone-induced mitosis was inhibited by the irs $1^{-/-}$ null mutants, we wanted to resolve whether the mutation compromised mitotic kinase activity. Cdk1 acquires the potential to become a mitotic kinase in mammalian cells when bound to cyclin B (Meijer et al. 1989). It is possible that the observed reduction in $\operatorname{cdk} 1$ (protein) in mutants prevented accumulation of enough mitotic kinase for mitosis. Alternatively, the mutation might affect posttranslational changes that regulate $\mathrm{cdk} 1$. Activation and inhibition of cdk1 kinase are known to occur by phosphorylation and dephosphorylation of specific sites, and it is likely that some of these modifications are integrated with growth factor pathways. The activation of AKT (Ser473 phosphorylation) can be demonstrated in our experimental model, as shown by the timecourse study in Fig. 5. AKT phosphorylation is clearly evident in the extracts from WT uterine epithelium obtained at 12 and $18 \mathrm{~h}$ following $\mathrm{E}_{2}$ treatment. Based on densitometric scans obtained at the 12-h time point, the $\mathrm{p}-\mathrm{AKT} / \mathrm{AKT}$ in irs $1^{-\prime-}$ mice $(0.55 \pm 0 \cdot 04$, mean \pm s.D. $)$ was significantly less $(P<0 \cdot 005)$ than that of WT mice $(1 \cdot 31 \pm 0 \cdot 16$, mean \pm s.D. $)$; $\mathrm{KO} / \mathrm{WT}=0 \cdot 42$. For the time-course experiment shown in Fig. 5, the p-AKT/AKT KO/WT ratios at 18 and $24 \mathrm{~h}$ after hormone treatment were similar to that reported at $12 \mathrm{~h}$ (data not shown). After $24 \mathrm{~h}$, the level of AKT phosphorylation was very weak in both the groups (Fig. 5). These findings support that an IRS-1-dependent pathway is utilized for the hormonal activation of uterine epithelial AKT. Other (non-IRS-1) signaling pathways probably account for the phosphorylation of AKT observed in mutant animals.

To determine whether the IRS-1 null mutation can affect mitotic kinase activity, uterine cyclin B-associated kinase 


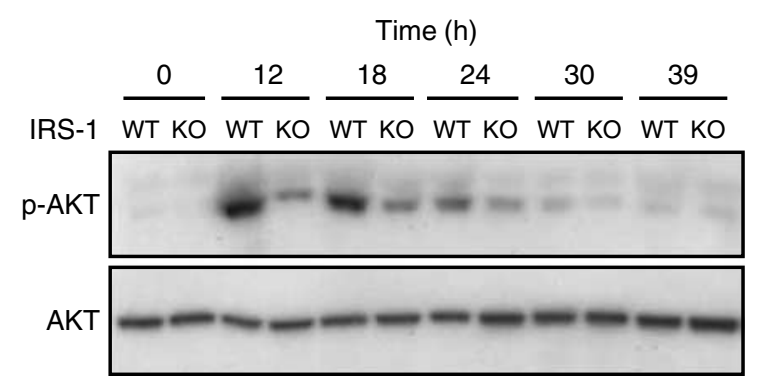

Figure 5 AKT phosphorylation in the uterine epithelium of estradiol-treated wild-type mice and $i r s 1^{-1-}(\mathrm{KO})$ mice. Ovariectomized wild-type (WT) and $i r s 1^{-1-}(\mathrm{KO})$ mice were treated with estradiol, and uterine epithelial extracts were obtained at the time points indicated. Mice at the 0 time point did not receive hormone. Each lane represents analyses of one uterus. Equal amounts of extracted protein (300-400 $\mu \mathrm{g})$ were used for WT and KO mice in each experiment. AKT was immunoprecipitated from extracts with $5 \mu \mathrm{g}$ anti-AKT antibody and immunoblots made with anti-phosphoAKT (Ser 473) and anti-AKT antibodies. Further details are described in Materials and Methods. The results shown are representative of four separate trials with different animals. Densitometric scans of the 12-h time point revealed that the uterine $\mathrm{p}-\mathrm{AKT} / \mathrm{AKT}$ in $\mathrm{KO}$ mice $(0.55 \pm 0 \cdot 04$, mean \pm s.D. $)$ was significantly less $(P<0 \cdot 005)$ than that of WT mice $(1 \cdot 31 \pm 0 \cdot 16$, mean \pm s.D. $) ; \mathrm{KO} / \mathrm{WT}=0 \cdot 42$.

activity was examined for up to $48 \mathrm{~h}$ following treatment of the mice with $E_{2}$. The phosphorylation of the histone H1 (exogenous) substrate was clearly evident at $20 \mathrm{~h}$ after hormone treatment in WT samples; however, much less kinase activity was observed at $48 \mathrm{~h}$ (Fig. 6A). This temporal pattern is in keeping with the importance of $\mathrm{cdk} 1 /$ cyclin $\mathrm{B}$ kinase activity for entry into the mitotic phase of the cell cycle (Lew \& Kornbluth 1996). The corresponding time-course study with samples from irs $1^{-/-}$uteri revealed much less phosphorylation of histone $\mathrm{H} 1$ than that obtained with WT samples. As determined by phosphoimaging, the cyclin B-associated kinase activity at $20 \mathrm{~h}$ after $\mathrm{E}_{2}$ treatment in irs $1^{-/-}$samples $\left(1 \cdot 25 \pm 0 \cdot 17 \times 10^{4}\right.$, mean \pm s.D. $)$ was significantly less $(P<0 \cdot 005)$ than that of WT samples $\left(3 \cdot 16 \pm 0 \cdot 22 \times 10^{4}\right.$, mean \pm s.D. $) ; \mathrm{KO} / \mathrm{WT}=0 \cdot 38$. This effect of the IRS-1 null mutation on hormonal activation of cyclin B-associated kinase activity was not observed with cyclin A-associated kinase activity. As shown in Fig. 6B, the

${ }^{32} \mathrm{P}$-labeling of the histone $\mathrm{H} 1$ substrate by kinase associated with cyclin A precipitates was comparable in the extracts from $\mathrm{WT}$ and $i r s 1^{-1-}$ mice. Immunoblots were made of cyclin B and cyclin A in the extracts obtained after $20 \mathrm{~h}$. The amount of each cyclin appeared comparable in WT and irs $1^{-1-}$ samples (Fig. 6B). Therefore, it is unlikely that the disparity between hormone-induced cyclin B-associated kinase activity in irs $1^{-/-}$and WT uteri could be explained by lower cyclin B levels.

Phosphorylation of $\mathrm{H} 1$ histone during mitosis entry is considered a downstream event of cdk1/cyclin B (Langan et al. 1989). Therefore, we examined the effect of the IRS-1 null mutation on hormone-induced phosphorylation of endogenous $\mathrm{H} 1$ histone with a phospho-specific (pThr18) antiserum to a cognate sequence of phospho (Thr18) mouse histone H1.3. As shown in Fig. 6C, three major bands corresponding to $\mathrm{H} 1$ isoforms were detected in the acid extracts of isolated uterine nuclei from $\mathrm{WT}$ and $i r s 1^{-/-}$mice. Twenty hours following hormone treatment, an immunoreactive band was observed in WT extracts that comigrated with the $\mathrm{H} 1.3 / \mathrm{H} 1.4$ isoforms. In contrast, hormone-induced phosphorylation of these isoforms isolated from irs $1^{-/-}$mice was much less than that observed with WT mice. This finding suggests that the activation of the IGF1/IRS-1 pathway by $\mathrm{E}_{2}$ can result in phosphorylation of endogenous histone.
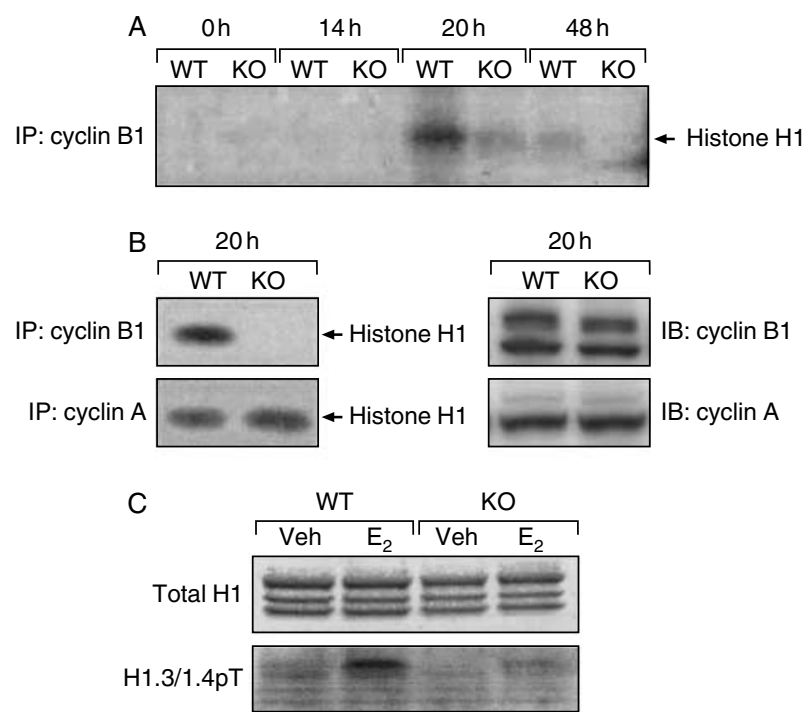

Figure 6 Cyclin A- and cyclin B- associated kinase activities in the wild-type and $i r s 1^{-1-}$ uterine epithelium. (A) Uterine epithelial extracts were obtained from ovariectomized wild-type (WT) and irs $1^{-1-}(\mathrm{KO})$ mice after the indicated interval following treatment with estradiol. Mice at the 0 time point did not receive estradiol. Cyclin B was immunoprecipitated from equal amounts $(\sim 400 \mu \mathrm{g}$ protein) of extracts from WT and KO uteri and analyzed for histone $\mathrm{H} 1$ kinase activity. More details of the immunoprecipitation and the kinase assay are described in Materials and Methods. The kinase samples were run on $4-20 \%$ Tris Ready Gels and then transblotted to Immobilon-P membrane. Specific quantitation of the ${ }^{32} \mathrm{P}$-labeled histone in the $20 \mathrm{~h} \mathrm{WT}$ and KO samples was made by phosphoimaging; $n=5$ for each group. Cyclin B-associated kinase activity associated with $\mathrm{KO}$ uterine samples $\left(1 \cdot 25 \pm 0 \cdot 17 \times 10^{4}\right.$, mean \pm S.D. $)$ was significantly less $(P<0 \cdot 005)$ than that of WT samples $\left(3 \cdot 16 \pm 0 \cdot 22 \times 10^{4}\right.$, mean \pm s.D.); KO/WT $=0 \cdot 38$. (B, left) Cyclin A- and cyclin B1-associated kinase activities were measured in uterine epithelial extracts obtained $20 \mathrm{~h}$ after hormone treatment. (B, right) Immunoblots were made of cyclin A and cyclin B1 in uterine epithelial extracts obtained from wild-type and mutant mice $20 \mathrm{~h}$ after hormone treatment. (C) Histones were enriched from whole uterine nuclear fractions, separated by $16 \%$ SDS-PAGE, and transblotted. The upper panel represents staining with Coomassie Blue; in the lower panel, the blot was probed with antiserum to mouse phospho (Thr18) histone $\mathrm{H} 1.3 / 1.4$ as described in Materials and Methods. Veh, represents extracts from vehicle-treated, or control, mice. The data in $A$ and $B$ are representative of five separate trials; the data in $\mathrm{C}$ are representative of three separate trials. Each trial used extracts from different mice, and each lane represents an extract from a single mouse uterus. 


\section{Discussion}

The use of the whole animal as an experimental model is important in accurately resolving the qualitative and quantitative responses of hormones. Cell cultures are generally inappropriate for studying estrogen-stimulated proliferation because of the requirement for normal epithelial/stromal interactions (Cooke et al. 1997, 2002). Cell cultures may not only be refractory to hormone action but also impose artifacts as a consequence of immortalization, high rate of cell turnover, or inappropriate activation of signaling pathways. This later aspect is particularly important in the present investigation where we are trying to link an $\mathrm{E}_{2}$-induced growth factor pathway with components of the cell cycle.

Since $\mathrm{E}_{2}$ treatment of ovariectomized igf $1^{-/-}$female mice failed to stimulate binding of p85 (PI3K) to IRS-1 in uterine epithelial cells, mice with the IRS-1 null mutation should reflect the importance of this adaptor protein as well as of IGF1 receptor signaling in response to $\mathrm{E}_{2}$. Earlier studies in this laboratory showed that $\mathrm{PI} 3 \mathrm{~K}$ was the only $\mathrm{SH} 2$ protein that bound to uterine IRS-1 following $\mathrm{E}_{2}$ treatment (Richards et al. 1998). Thus, the absence of IRS-1 should barring any adaptive changes in the null mutant - selectively deprive the uterine epithelial cell of that pool of PI3K that becomes catalytically active by binding to IRS-1 as a consequence of $\mathrm{E}_{2}$ stimulation of the IGF1 receptor pathway. It was previously reported that stimulation of PI3K activity by IGF1 in $i r 1^{-1-}$ mouse embryonic fibroblasts was reduced by $70 \%$ when compared with that of $i r s 1^{+/+}$cells (Bruning et al. 1997). Mouse embryonic cells, along with uterine cells, contain IRS-2, which can also bind and activate PI3K (Sun et al. 1995). This IRS isoform does not functionally supplant IRS-1 in the embryonic fibroblasts. In addition, after $\mathrm{E}_{2}$ treatment, uterine IRS-2 is degraded through an IGFstimulated, proteasome-dependent pathway, while levels of IRS-1 remain essentially unchanged (Richards et al. 2001).

The IRS-1 null mutation did not significantly alter the fraction of uterine epithelial cells undergoing DNA synthesis in response to $\mathrm{E}_{2}$; however, this mutation markedly reduced the fraction of cells undergoing mitosis. These data are very similar to the cytokinetic response to $E_{2}$ in uterine cells of igf $1^{-1-}$ mice (Adesanya et al. 1999). In a broad sense, these findings indicate that a growth factor pathway can regulate a specific stage, e.g. mitosis, of the cell cycle. Thus, we can propose that an IGF1R/IRS-1/PI3K pathway stimulates the rate of mitosis in the uterine epithelium in response to estrogens. There are several reports where cell lines were used to demonstrate that a signaling pathway downstream from $\mathrm{PI} 3 \mathrm{~K} / \mathrm{AKT}$ functions in the $\mathrm{G}_{2} \rightarrow \mathrm{M}$ transition of the cell cycle. In synchronized HeLa or MDCK cells, AKT activity was maximal during the $G_{2}$ /early $M$ phase and then dropped precipitously as cells completed mitosis (Shtivelman et al. 2002). Inhibition of PI3K in these cells prevents the activation of cyclin B-associated kinase and elicits $\mathrm{G}_{2}$ arrest that can be abolished by activated AKT. In HEK293 cells, inhibition of
PI3K also induces a $G_{2}$ cell cycle arrest that could be alleviated by activated AKT. Mouse embryonic fibroblasts with an AKT1 null mutation revealed a delayed transition from $\mathrm{G}_{2} / \mathrm{M}$ to $G_{1}$ (Kandel et al. 2002). In this study, the reduction in PI3K/AKT activation caused by the IRS-1 null mutation apparently led to a loss of specific stimulation of the $G_{2} \rightarrow M$ transition. The component(s) of the cell cycle regulated by the hormonally stimulated IRS-1/PI3K/AKT that would specifically influence the mitotic phase is unknown.

In accordance with the reduced rate of $\mathrm{E}_{2}$-induced mitosis in uterine cells of $i r 1^{-/-}$mice, there was a marked reduction in cyclin B-associated kinase activity. Other cdks cannot supplant the function of cdk1 as a mitotic kinase in mammalian cells (Nurse 1990, Nigg 1993). On the other hand, cdk1 can associate with A- and B-type cyclins in mammalian cells to phosphorylate histone H1 (Loyer et al. 1994, Swank et al. 1997). Since levels of cyclin A, cdk2, and cyclin A-associated H1 kinase activity were not affected by the IRS-1 null mutation, it is likely that cyclin A predominantly functions in uterine cells as a complex with cdk2. This would favor the notion that IGF1R signaling in these cells targets cdk1, and not other cdks, such as cdk2. The level of cdk1 in the IRS-1 null mutants prior to mitosis was less than that in WTs, which could delay the formation of the threshold concentration of the mitotic kinase (heterodimer). Since the lower levels of cdk1 protein could not be explained by a corresponding decrease in transcript, altered signaling in the mutant might have reduced translation or half-life of cdk1. Earlier studies showed that IRS-1 and PI3K were required for insulin to stimulate eIF-4E/4E-BP-1 phosphorylation and translation in cultured cells (Mendez et al. 1996). Using phospho-specific antisera, we demonstrated that the translation effectors mechanistic target of rapamycin, tuberin, 4E-BP1, eIF-4E, p70S6 kinase, and glycogen synthase kinase 3 are activated in response to $E_{2}$; however, we could not demonstrate an effect of the IRS-1 null mutation on specific phosphorylation of these translational components (data not shown). To our knowledge, this specific effect of the IGF1R signaling on cdk1 protein levels has not been previously reported. One study did suggest that translational control of $\mathrm{cdk} 1\left(\mathrm{p} 34^{\mathrm{cdc} 2}\right)$ was associated with meiotic competence of mouse oocytes; incompetent oocytes have abundant $c d k 1 \mathrm{mRNA}$ but low levels of $c \mathrm{dk} 1$ protein (deVantery et al. 1997). Our experimental model may have allowed us to identify changes in cell cycle components that do not occur or are obscured by most cells in culture. With many immortalized cell lines, for instance, the cdk1 protein is expressed at all stages of the cell cycle (McGowan et al. 1990, Welch \& Wang 1992, Draetta \& Beach 1998). However, there are aspects of cdk1 transcripts in mammalian cell cultures that overlap with those observed in animal studies. For instance, cdk1 transcription in HeLa cells is elevated in the $S$ and $G_{2}$ phases and low in the $G_{1}$ phase of the cell cycle, based on nuclear run-on assays (Dalton 1992). Likewise, other studies with HeLa cells revealed that the abundance of $c d k 1$ mRNA and rate of synthesis of cdk1 protein (p34) increase dramatically as the cells pass through $\mathrm{S} / \mathrm{G}_{2}$ (Welch $\&$ Wang 1992). 
Since the KO/WT for $\mathrm{p}-\mathrm{AKT} / \mathrm{AKT}$ was similar at different times $(12,18$, and $24 \mathrm{~h})$ after hormone treatment, it is likely that the IRS-1 null mutation does not affect the rate of p-AKT dephosphorylation at Ser473. During the period when uterine AKT phosphorylation was elevated in WT and irs $1^{-1-}$ mice, AKT was essentially unchanged from that of untreated mice; the increased level of AKT observed after $24 \mathrm{~h}$ following treatment with $E_{2}$ is in keeping with the known increase in AKT transcripts in response to this hormone (Hewitt et al. 2003). It was reasonable to expect in our model that the IRS-1 null mutation would cause a pronounced reduction in AKT activation. Previous reports suggest that enzymes that regulate phosphorylation and activity of the mitotic kinase are proximal targets of AKT. For instance, phosphorylation at Thr14 and Tyr15 of cdk1 by Myt1, a member of the Wee family of kinases, inhibits the kinase activity of cdk1 (Mueller et al. 1995). In a study with starfish oocytes, it was shown that AKT, acting downstream from PI3K, phosphorylates Myt1 and downregulates its activity, which favors the meiotic $\mathrm{G}_{2} / \mathrm{M}$ phase transition (Okumura et al. 2002). A related study showed that AKT can phosphorylate Wee 1 in 293T or HeLa cells, which promotes cytoplasmic localization at the kinase (by binding to 14-3-3q), and $\mathrm{G}_{2} / \mathrm{M}$ cell progression (Katayama et al. 2005). Thus, it is possible that a deficient PI3K/AKT signaling pathway in the IRS-1 null mutants increases phosphorylation at Thr14/Tyr15 of cdk1 and thereby compromises its kinase activity. Alternatively, AKT might also be activating cdc25C, which dephosphorylates Thr14/Tyr15 of cdk1. Inhibition of PI3K by LY294002 in HeLa cells delays hyperphosphorylation of cdc25C and cells entering mitosis (Dangi et al. 2003). However, it is still not known whether a PI3K/AKT pathway is activating for cdc25C, directly or indirectly. In another study, wortmannin, a potent inhibitor of PI3K, partially inhibited cyclin B translation and inhibited dephosphorylation of the tyrosine (inhibitory) site of cdk1 of sea urchin oocytes (Salaün et al. 2002). In the later study, the effects of wortmannin on cyclin B synthesis (triggered by fertilization) were also correlated with the effects of this compound on cap-dependent translation machinery, which included 4E-BP/eIF-4E dissociation. AKT facilitates the $\mathrm{G}_{2} / \mathrm{M}$ phase transition of mouse PC12 neuronal cells (Lee et al. 2005). Stable expression of a dominant negative form of AKT suppressed expression of both cdk1 and cyclin B1 at the mRNA and protein levels without affecting the cyclin A or cdk2 protein levels. A constitutively active form of AKT (myristoylated AKT) elevated cyclin B and cdk1 mRNA and protein levels and could override cell growth arrest at $G_{2} / M$ (induced by etoposide).

The present finding that the hormone-induced phosphorylation of an endogenous histone H1 isoform in WTs clearly exceeded that of irs $1^{-/-}$mice is in accordance with the observed decrease of cyclin B-associated kinase activity in the mutant animals. The purified cdk1/cyclin B heterodimer phosphorylates specific sites on histone $\mathrm{H} 1$ in vitro (Swank et al. 1997). Earlier studies had also provided evidence to show that the cdks are the major in vivo kinases for $\mathrm{H} 1$ at cell cycle transitions with cdk1 implicated as the $\mathrm{G}_{2}$ kinase for $\mathrm{H} 1$ (Langan et al. 1989). The phosphorylation of histone H1 in vivo by a cdk is considered to destabilize $\mathrm{H} 1-$ chromatin interactions and, thereby, facilitate a more open chromatin structure (Contrera et al. 2003). Thus, by regulating cyclin B-associated kinase activity an IGF1R/IRS-1/PI3Kstimulated signaling cascade mediates hormonal effects on the state of chromatin condensation. A query to consider for postmenopausal females receiving prolonged exposure to estrogens is whether the perturbation of chromatin structure by this signaling pathway facilitates genomic instability and increased risk of endometrial cancer (Enders \& Maude 2006).

Our cumulative findings support that the stimulation of uterine epithelial cell proliferation by $\mathrm{E}_{2}$ is mediated by an IGF1/IRS-1/PI3K/AKT pathway, and that this pathway targets the mitotic kinase $\mathrm{cdk} 1 /$ cyclin $\mathrm{B}$. A specific goal of future work should determine whether impairment of AKT activity by the IRS-1 null mutation affects the activity of enzymes or other proteins that regulate posttranslational changes or catalytic activity of cdk1. Other cell populations might have mechanisms to regulate mitotic kinase activity that are similar to or overlap with those observed in this study. In a broad sense, our experimental findings are probably part of a more general phenomenon, where individual growth factors exert stage-specific regulation of the cell cycle by activating or suppressing specific cyclin-associated kinases.

\section{Declaration of interest}

The authors declare that there is no conflict of interest that could be perceived as prejudicing the impartiality of the research reported.

\section{Funding}

This research was supported by the Intramural Research Program of the National Institute of Environmental Health Sciences, NIH; project number Z01 ES071006-09.

\section{Acknowledgements}

We thank Drs C Ronald Kahn and Argiris Efstratiadis for providing mice with an IRS-1 null allele and IGF1 null allele respectively. We thank Jesse DeGraff for supervising the breeding of the mutant mice. The assistance given by Janice Hicks, Maureen Trogdon, Ervin Smallwood, Colleen Anna, and Wes Gladwell is also greatly appreciated. We thank James Clark and Page Meyers for reliably preparing ovariectomized mice throughout the study. Sylvia C Hewitt and Dr Bonnie Deroo are gratefully acknowledged for providing the mouse uterine microarray data. The critique of the manuscript by Tom Gray, Sylvia C Hewitt, and Dr Grace E Kissling is also greatly appreciated.

\section{References}

Adesanya OO, Zhou J, Samathanam C, Powell-Braxton L \& Bondy CA 1999 Insulin-like growth factor 1 is required for $G_{2}$ progression in the estradiol-induced mitotic cycle. PNAS 96 3287-3291. (doi:10.1073/ pnas.96.6.3287) 
Altucci L, Addeo L, Cicatiello L, Germano D, Pacilio C, Battista T, Cancemi M, Petrizzi VB, Bresciani F \& Weisz A 1997 Estrogen induces early and timed activation of cyclin-dependent kinases 4, 5, and 6 and increases cyclin messenger ribonucleic acid expression in rat uterus. Endocrinology 138 978-984. (doi:10.1210/en.138.3.978)

Araki E, Lipes MA, Patti ME, Bruning JC, Haag BL III, Johnson RS \& Kahn CR 1994 Alternative pathway of insulin signaling in mice with targeted disruption of the IRS-1 gene. Nature 372 186-190. (doi:10.1038/ 372186a0)

Archer TK, Cordinley MG, Wolford RG \& Hager GL 1991 Transcription factor access is mediated by accurately positioned nucleosomes on the mouse mammary tumor virus promoter. Molecular and Cellular Biology 11 688-698.

Baker J, Hardy MP, Zhou J, Bondy C, Lupu F, Bellvre AR \& Efstratiadis A 1996 Effects of an Igf1 gene null mutation on mouse reproduction. Molecular Endocrinology 10 903-918. (doi:10.1210/me.10.7.903)

Bruning JC, Winnay J, Cheatham B \& Kahn CR 1997 Differential signaling by insulin receptor substrate 1 (IRS-1) and IRS-2 in IRS-1-deficient cells. Molecular and Cellular Biology 17 1513-1521.

Campisi J \& Pardee AB 1984 Post-translational control of the onset of DNA synthesis by an insulin-like growth factor. Molecular and Cellular Biology $\mathbf{4}$ 1807-1814.

Contrera AA, Hale TK, Stenoien DL, Rosen JM, Mancini MA \& Herrera RE 2003 The dynamic mobility of histone H1 is regulated by cyclin/cdk phosphorylation. Molecular and Cellular Biology 23 8626-8636. (doi:10. 1128/MCB.23.23.8626-8636.2003)

Cooke PS, Buchanan DL, Young P, Setiawan T, Brody J, Korach KS, Taylor J, Lubahn DB \& Cunha GR 1997 Stromal estrogen receptors mediate mitogenic effects of estradiol on uterine epithelium. PNAS 94 6535-6540. (doi:10.1073/pnas.94.12.6535)

Cooke PS, Buchanan DL, Kurita T, Lubahn DB \& Cunha GR 2002 Role of stromal-epithelial interactions in hormonal responses in the uterus. In The Endometrium, pp 151-166. Eds SR Glasser, JD Alpin, LC Giudice \& $S$ Tabibzadeh. London: Taylor \& Francis.

Couse JF, Curtis SW, Washburn TF, Lindzey J, Golding TS, Lubahn DB, Smithies O \& Korach KS 1995 Analysis of transcription and estrogen insensitivity in the female mouse after targeted disruption of the estrogen receptor gene. Molecular Endocrinology 9 1441-1454. (doi:10.1210/ me.9.11.1441)

Dalton S 1992 Cell cycle regulation of the human cdc2 gene. EMBO Journal 11 1797-1804.

Dangi S, Cha H \& Shapiro P 2003 Requirement for phosphatidylinositol-3 kinase activity during progression through S-phase and entry into mitosis. Cellular Signalling 15 667-675. (doi:10.1016/S0898-6568(03)00002-0)

Deterding LJ, Bunger MK, Banks GC, Tomer KB \& Archer TK 2008 Global changes in and characterization of specific sites of phosphorylation in mouse and human histone $\mathrm{H} 1$ isoforms upon CDK inhibitor treatment using mass spectrometry. Journal of Proteome Research 7 2368-2379. (doi:10. 1021/pr700790a)

Draetta G \& Beach D 1998 Activation of cdc2 protein kinase during mitosis in human cells: cell cycle-dependent phosphorylation and subunit rearrangement. Cell 54 17-26. (doi:10.1016/0092-8674(88)90175-4)

Enders GH \& Maude SL 2006 Traffic safety for the cell: influence of cyclin-dependent kinase activity on genomic stability. Gene 371 1-6. (doi:10.1016/j.gene.2005.11.017)

Fagg B, Martin L, Rogers LA, Clark BF \& Quarmby VE 1979 A simple method for preparing pure samples of uterine cells. Journal of Reproduction and Fertility 57 335-345. (doi:10.1530/jrf.0.0570335)

Gambrell RD, Bagnell CA \& Greenblatt RB 1983 Role of estrogens and progesterone in the etiology and prevention of endometrial cancer: review. American Journal of Obstetrics and Gynecology 146 696-707.

Hewitt SC, Deroo BJ, Hansen K, Collins J, Grissom S, Afshari CA \& Korach KS 2003 Estrogen receptor-dependent genomic responses in the uterus mirror the biphasic physiological response to estrogen. Molecular Endocrinology 17 2070-2083. (doi:10.1210/me.2003-0146)

Kandel ES, Keen JS, Majewski N, DiCristofano A, Pandolfi PP, Feliciano CS, Gartel A \& Hay N 2002 Activation of Akt/protein kinase B overcomes a $\mathrm{G}_{2} / \mathrm{M}$ cell cycle checkpoint induced by DNA damage. Molecular and Cellular Biology 22 7831-7841. (doi:10.1128/MCB.22.22.78317841.2002)

Katayama K, Fujita N \& Tsuroro T 2005 Akt/protein kinase B-dependent phosphorylation and inactivation of WEE1Hu promote cell cycle progression at $\mathrm{G}_{2} / \mathrm{M}$ transition. Molecular and Cellular Biology 25 5725-5737. (doi:10.1128/MCB.25.13.5725-5737.2005)

Kim YH, Proust JJ, Buchholz MJ, Chrest FJ \& Nordin AA 1992 Expression of the murine homologue of the cell cycle control protein $\mathrm{p} 34^{\text {cdc2 }}$ in $\mathrm{T}$ lymphocytes. Journal of Immunology 149 17-23.

Klotz DM, Curtis Hewitt S, Korach KS \& DiAugustine RP 2000 Activation of a uterine insulin-like growth factor I signaling pathway by clinical and environmental estrogens: requirement of estrogen receptor- $\alpha$. Endocrinolog $\gamma$ 141 3430-3439. (doi:10.1210/en.141.9.3430)

Langan TA, Gautier J, Lohka M, Hollingsworth R, Moreno S, Nurse P, Maller J \& Sclafani RA 1989 Mammalian growth-associated H1 histone kinase: a homolog of $\mathrm{cdc} 2+/ \mathrm{cdc} 28$ protein kinases controlling mitotic entry in yeast and frog cells. Molecular and Cellular Biology 9 3860-3868.

Lee S-R, Park JH, Park EK, Chung CH, Kang S-S \& Bang OS 2005 Akt-induced promotion of cell-cycle progression at $\mathrm{G}_{2} / \mathrm{M}$ phase involves upregulation of NF-Y binding activity in PC12 cells. Journal of Cellular Physiology 205 270-277. (doi:10.1002/jcp.20395)

Lembo G, Rockman HA, Hunter JJ, Steinmetz H, Koch WJ, Ma L, Prinz MP, Ross K Jr, Chien KR \& Powell-Braxton L 1996 Elevated blood pressure and enhanced myocardial contractility in mice with severe IGF-1 deficiency. Journal of Clinical Investigation 98 2648-2655. (doi:10.1172/ JCI119086)

Leof EB, Wharton W, van Wyk JJ \& Pledger WJ 1982 Epidermal growth factor (EGF) and somatodmedin $C$ regulate $\mathrm{G}_{1}$ progression in competent BALB/c-3T3 cells. Experimental Cell Research 141 107-115. (doi:10.1016/ 0014-4827(82)90073-8)

Lew DJ \& Kornbluth S 1996 Regulatory roles of cyclin dependent kinase phosphorylation in cell cycle control. Current Opinion in Cell Biology 8 795-804. (doi:10.1016/S0955-0674(96)80080-9)

Liu JP, Baker J, Perkins AS, Robertson EJ \& Efstratiadis A 1993 Mice carrying null mutations of the genes encoding insulin-like growth factor 1 (IGF-1) and type 1 IGF receptor (IGF1r). Cell 75 59-72. (doi:10.1016/ S0092-8674(05)80084-4)

Lowe WL 1991 Biological actions of the insulin-like growth factor. In Insulin-Like Growth Factors: Molecular and Cellular Aspects, pp 49-85. Ed. D LeRoith. Boca Raton, FL: CRC Press.

Loyer P, Glaise D, Cariou S, Baffet G, Meijer L \& Guguen-Guillouzo C 1994 Expression and activation of cdks (1 and 2) and cyclins in the cell cycle progression during liver regeneration. Journal of Biological Chemistry 269 2491-2500.

McGowan CH, Russell P \& Reed SI 1990 Periodic biosynthesis of the human M-phase promoting factor catalytic subunit p34 during the cell cycle. Molecular and Cellular Biology 10 3847-3851.

Meijer L, Arion D, Golsteyn R, Pines J, Brizuela L, Hunt T \& Beach D 1989 Cyclin is a component of the sea urchin egg M-phase specific histone H1 kinase. EMBO Journal 8 2275-2282.

Mendez R, Myers MG Jr, White MF \& Rhoads RE 1996 Stimulation of protein synthesis, eukaryotic translation initiation factor 4E phosphorylation, and PHAS-I phosphorylation by insulin requires insulin receptor substrate 1 and phosphatidylinositol 3-kinase. Molecular and Cellular Biology $162857-2864$.

Minshull J, Goldsteyn R, Hill CS \& Hunt T 1990 The A- and B- type cyclin associated cdc2 kinases in Xenopus turn on and off at different times in the cell cycle. EMBO Journal 9 2865-2875.

Mueller PR, Coleman TR, Kumagai A \& Dunphy WG 1995 Myt1: a membrane-associated inhibitory kinase that phosphorylates $\mathrm{cdc} 2$ on both threonine-14 and tyrosine-15. Science 270 86-90. (doi:10.1126/science. 270.5233.86)

Murphy LJ, Murphy LC \& Friesen HG 1987 Estrogen induces insulin-like growth factor-1 expression in the rat uterus. Molecular Endocrinology 1 445-450. (doi:10.1210/mend-1-7-445) 
Nigg EA 1993 Cellular substrates of $\mathrm{p} 34^{\mathrm{cdc} 2}$ and its companion cyclin-dependent kinases. Trends in Cell Biology 3 296-301. (doi:10.1016/0962-8924(93) 90011-O)

Nurse P 1990 Universal control mechanism regulating onset of M-phase. Nature 344 503-508. (doi:10.1038/344503a0)

Okumura E, Fukuhara T, Yoshida H, Hanada S, Kozutsumi R, Mori M, Tachibana K \& Kishimoto T 2002 Akt inhibits Myt1 in the signaling pathway that leads to meiotic $\mathrm{G}_{2} / \mathrm{M}$-phase transition. Nature Cell Biology 4 111-116. (doi:10.1038/ncb741)

Osborne CK, Coronado EB, Kitten LJ, Arteaga CI, Fuqua SA, Ramasharma K, Marshall M \& Li CH 1989 Insulin-like growth factor-II (IGF-II): a potential autocrine/paracrine growth factor for human breast cancer acting via the IGF-1 receptor. Molecular Endocrinology 3 1701-1709. (doi:10.1210/ mend-3-11-1701)

Pfaffl MW 2001 A new mathematical model for relative quantification in real-time RT-PCR. Nucleic Acids Research 29 e45 (online). (doi:10.1093/ nar/29.9.e45)

Richards RG, DiAugustine RP, Petrusz P, Clark GC \& Sebastian J 1996 Estradiol stimulates tyrosine phosphorylation of the insulin-like growth factor-1 receptor and insulin receptor substrate-1 in the uterus. PNAS 93 12002-12007. (doi:10.1073/pnas.93.21.12002)

Richards RG, Walker MP, Sebastian J \& DiAugustine RP 1998 Insulin-like growth factor-1 (IGF-1) receptor-insulin receptor substrate complexes in the uterus. Altered signaling response to estradiol in the IGF- $1^{\mathrm{m} / \mathrm{m}}$ mouse. Journal of Biological Chemistry 273 11962-11969. (doi:10.1074/jbc.273.19. 11962)

Richards RG, Klotz DM, Bush MR, Walmer DK \& DiAugustine RP $2001 \mathrm{E}_{2}$-induced degradation of uterine insulin receptor substrate-2: requirement for an IGF-1-stimulated, proteasome-dependent pathway. Endocrinology 142 3842-3849. (doi:10.1210/en.142.9.3842)

Rose DW, Saltile AR, Majumdar M, Decker SJ \& Olefsky JM 1994 Insulin receptor substrate 1 is required for insulin-mediated mitogenic signal transduction. PNAS 91 797-801. (doi:10.1073/pnas.91.2.797)

Salaün P, LeBreton M, Morales J, Belle R, Boulben S, Mulner-Lorillon O \& Cormier P 2002 Signal transduction pathways that contribute to CDK1/cyclin B activation during the first mitotic division in sea urchin embryos. Experimental Cell Research 296 347-357. (doi:10.1016/j.yexcr. 2004.02.013)
Sell C, Dumenil G, Deveaud C, Miura M, Coppola D, DeAngelis T, Rubin R, Efstratiadis A \& Baserga R 1994 Effect of a null mutation of the type 1 IGF receptor gene on growth and transformation of mouse embryo fibroblasts. Molecular and Cellular Biology 14 3604-3612.

Shtivelman E, Sussman JS \& Stokoe D 2002 A role for PI 3-kinase and PKB activity in the $\mathrm{G}_{2} / \mathrm{M}$ phase of the cell cycle. Current Biology $12919-924$. (doi:10.1016/S0960-9822(02)00843-6)

Sun XJ, Wang LM, Zhang Y, Yenush L, Myers MG Jr, Glasheen EM, Lane WS, Pierce JH \& White MF 1995 Role of IRS-2 in insulin and cytokine signaling. Nature 377 173-177. (doi:10.1038/377173a0)

Swank RA, Th'ng JPH, Guo X-W, Valdez J, Bradbury EM \& Gurley LR 1997 Four distinct cyclin-dependent kinases phosphorylate histone H1 at all of its growth-related phosphorylation sites. Biochemistry 36 13761-13768. (doi:10.1021/bi9714363)

Tong W \& Pollard JW 1999 Progesterone inhibits estrogen-induced cyclin D1 and cdk4 nuclear translocation, cyclin E-and cyclin A-cdk2 kinase activation, and cell proliferation in uterine epithelial cells in mice. Molecular and Cellular Biology 19 2251-2264.

Tong W \& Pollard JW 2002 Female sex steroid hormone regulation of cell proliferation in the endometrium. In The Endometrium, pp 94-109. Eds SR Glasser, JD Aplin, LC Giudice \& S Tabibzadeh. London: Taylor $\&$ Francis.

deVantery C, Stutz A, Vassalli JD \& Schorderet-Slatkine S 1997 Acquisition of meiotic competence in growing mouse oocytes is controlled at both translational and posttranslational levels. Developmental Biology 187 43-54. (doi:10.1006/dbio.1997.8599)

Waters SB, Yamauchi K \& Pessin JE 1993 Functional expression of insulin receptor substrate-1 is required for insulin-stimulated mitogenic signaling. Journal of Biological Chemistry 268 22231-22234.

Welch PJ \& Wang JYJ 1992 Coordinated synthesis and degradation of cdc2 in the mammalian cell cycle. PNAS 89 3093-3097. (doi:10.1073/ pnas.89.7.3093)

Received in final form 18 August 2010

Accepted 26 August 2010

Made available online as an Accepted Preprint 26 August 2010 